\title{
Assistência Técnica Internacional
}

$\mathrm{T}$

ORNOU-SE de hábito por parte de administradores e economistas a referência quase obrigatótia aos problemas de assistência técnica. E' expressão que obteve, junto ao especialista e leigo, o prestigio dus grandes idéias que trazem em si o generoso impulso da contuvência humana. Da assistência técnica pode dizer-se que tem, hoje livre trânsito na cátedra, nas assembléias mundiais e nos organismos oficiais.

Não se trata, porém, de fenômeno recente, fruto de condições especificas do nosso sćculo. Suas origens vão longe no tempo, e o Professor PEter Lengyel identifica, na evolução da assistência técnica, alguns antecedentes como êstes: adaptação de técnicas de um determinado meio para outro; imitação de métodos consagrados no estrangeiro e a transferência de inovações.

O contexto histórico em que se desenvolveu é, assim, muito vasto e não limitadc a umas poucas manifestações, pois que até a imigração, forçada ou espontânea, parece encontrar-se entre os fatôres que propiciaram a transplantação de técnicas e de saberes para além de fronteiras nacionais, tribais e de civilizações.

O que realmente há de nôvo nessa forma de solidariedade tão em voga é a sua concretização em têrmos institucionais. Antes intermitente, lenta e vacilante, a assistência técnica afirma-se, agora, de maneira orgânica e permanente. Develse aos inglêses - primeiro texto legal sôbre a matéria, segundo as disposições contidas no British Colonial Development and Welfare Program de 1929.

Politicos sensiveis às realidades do imenso império que dominaram, cedo comprenderam a importância da assistência técnica para assegurar a presença da inglaterra nos mais diferentes pontos da terra. Presença não eternamente bem-vinda, pois as comunidades politicamente mais ev luidas foram, por sua vez. proila- 
mando a necessidade de uma distribuição mais equitativa de riquezas e de una mais efetiva difusão do progresso, entre as nações.

Formou-se pouco a pouco, em conseqüência dêsse estado de espirico reinvindicante, uma autêntica consciência universal dos problemas de uma humanidade dividida em nações ricas e pobres. A tal ponto dividida que foi possivel o aparecimento, senão de uma ciência, mas de estudos e conhecimentos especiais dedicados aos paises subdesenvolvidos geogràficamente reunidos num todo pela semelhança de suas estruturas globais.

Pois é a êsses países, cêrca de setenta, carentes de qualquer indice expressivo de progresso, que a assistência técnica internacional procura fornecer, sob múltiplas formas, os elementos indispensáveis à solução dos seus dramas sociais, econômicos e culturais.

Estabelecida cotn o tropósito desinteressado de ajuda, a assistência técnica processa-se por meio de organismos que comportam um quadro de cientistas $€$ butrocratas encarregados da elaboração e execução dos vários programas em cogitação. Que seja bilateral ou regional, o sucesso dos empreendimentos dependerá em larga escala das reais motivações que deram ensejo à assitência concedida e solicitada.

Em principio neutra, a menor interferência de consideração de ordem pclitica ou mercantil retirará, de antemão, à assistência os beneficios e os méritos perseguidos. Dai porque uma verdadeira assistência técnica devesse realizar-se sempre no nivel de organizações internacionais do tipo da ONU, de indiscutivel imparcialidade, pelo caráter supranacional de suas finalidades.

O programa de assistência da ONU vem sendo, aliás, cumprido com algum êxito e compreende conselhos técnicos, formação de peritos, demonstrações com o objetivo de aperfeiçoar e difundir as diversas técnicas, o estabelecimento de planos pilotos, a vulgarização da informação cientifica e a concessão de bôlsas de estudo.

Aciotado em 1949 pelo Conselho Econômico e Social das Nações UInidas, um outro programa ampliado, em oposição a de rotina, prevê inclusive um item referente à assistência técnica em matéria de adninistração pública. Em qualquer hipótese, a assis- 
tência técnica da ONU deverá ser solicitada pelo pais interessado, destina-se aos governos e não deverá ser pretexto para nenhuma ingerênita econômica ou politica.

Lamentàvelmente, os recursos técnicos e financeiros da ONU não bastam para garantir a expansão de suas atividades num setor em que a demancla cresce de modo vertiginoso. Uma simples citação ilustrará o esfôrço já feito: De 1950 a 1954, perto de 5.764 peritos da ONU partiram em missão nos paises subdesenvolvidos e 3.691 bôlsas de estudo foram concedidas, no mesmo periodo. Já em 1955, nada menos de 2.000 peritos empreendiam idênticas missões e 3.000 bôlsas eram também distribuidas.

A insuficiência da ação da ONU pôs, assim, uma considetável faixa de paises subdesenvolvidos à mercê dos planos de assistência concebicios em função de acôrdos bilaterais (Ponto IV) ou regionais (Plano de Colombo), cujos resultados não estão isentos de falhas e criticas.

Cens!tra-se com freqüêricia os acôrdos bilaterais ou regionais porque, de ordinário, o país doador da assistência impõe cláusulas ao pais bene[iciátin ncm sempre condizentes com os objetivos de indole estritamente técnicos que inspiram a celebração dos mesmos e que são, por excmplo, inerentes à assistência praticada pela ONUI.

Mas a censura mais grave que se poderá levantar contra êsses acôrdos é que êles estão sendo o instrumento de uma competição internacional que visa a conseguir, para alguns paises ou grupos de paises em aliança, vantagens que chegam à penetração ideológira e à conquista de mercados para a mão-de-obra especializado exceciente.

Nesse sentido, tem-se falado que a assistência técnica internacional passou a ser um simples artigo de exportação, de alto teor propagandistico e comercial... Veremos oportunamente e como os Estados Unidos da América e a União Soviética comportam-s.: nessa luta desenfreada, como os protagonistas mais fortes.

No entrechoque de uma tal competição, onde há lugar para várias estratégias, a assistência técnica perde em substância e conteúdo, deixando de ser uma manifestação de solidariedade. 
para transformar-sr $\mathrm{em}$ objeto de uma transação nominalmente diplomática. Não é outro o desencanto que aflige respeitáveis socioólogos e filósofos da problemática do nosso tempo. Pôde assim FrancoIs PERRoux protestar, em palavras candentes, contra a "avareza das nações", que, segundo êle, "nada cede gratuitamente e sacrifica a vida às coisas".

Quando peritos da ONU estimam em dez bilhões de dólares a soma anual necessária para a decolagem dos paises subdesenvolvidos, os programas de assistência técnica internactonal em curso representam, antes, um desafio à paciência dos oprimidos do que uma esperança dc solução para os numerosos problemas aule thes dificultarn o caminho do progresso. 